\title{
Links between Bloom's Taxonomy and Gardener's Multiple Intelligences: The issue of Textbook Analysis
}

\author{
Mahmoud Abdi Tabari (Corresponding author) \\ Oklahoma State University, Stillwater, OK, USA \\ E-mail: abditab@okstate.edu \\ Iman Abdi Tabari \\ Mazandaran Education Organization \\ Farhangian University, Sari, Mazandaran, Iran \\ E-mail: imanabdi05@yahoo.com
}

Doi:10.7575/aiac.alls.v.6n.1p.94

Received: 20/09/2014

URL: http://dx.doi.org/10.7575/aiac.alls.v.6n.1p.94

Accepted: 25/11/2014

\begin{abstract}
The major thrust of this research was to investigate the cognitive aspect of the high school textbooks and interchange series, due to their extensive use, through content analysis based on Bloom's taxonomy and Gardner's Multiple Intelligences (MI). This study embraced two perspectives in a grid in order to broaden and deepen the analysis by determining the numbers and the types of intelligences with respect to their learning objectives tapped in the textbooks and comparing them. Through codification of Bloom's learning objectives and Gardner's MI, the results showed that there was a significant difference between the numbers of intelligences with respect to their learning objectives in the textbooks. However, the interchange series enjoyed a large number of the spatial and the interpersonal intelligences across eight levels of learning objectives, whereas they had the least number of the intrapersonal, the musical, and the bodily-kinesthetic intelligences across knowledge understanding and application levels.
\end{abstract}

Keywords: learning objectives, multiple intelligences, textbook analysis

\section{Introduction}

Multiple intelligences (MI) has been an important research issue in recent years due to its extension of presenting different ways of learning for different kinds of learners and a framework for teachers to make sense of their learners learning styles. To achieve learning objectives at wider and deeper levels, Bloom's taxonomy was integrated to Gardner's multiple intelligences. Bloom's taxonomy of educational objectives, in cognitive domains, is a cognitive hierarchy that orders cognitive processes from single to complex ones. To this end, a planning tool was devised to determine breadth and depth of learning processes and goals in textbooks both for the teachers and the learners. Two recent research studies conducted to determine the learning objectives and evidence of MI in the textbooks by Riazi and Mosalanejad (2010) focused merely on Bloom's taxonomy and Shirvani (2010) investigated MI evidences in some books. Both of them viewed the materials from a single perspective resulting in one-dimension analysis. However, Nobel $(2000,2004)$ integrated the two taxonomies to perform the objectives of teaching through tasks in order to gain wider and deeper understanding and learning in primary schools. Although the focus of study did not concern language education, it gave a clear perspective to consider textbook content thoroughly. Very little research to date has focused on the two perspectives together in English language teaching (ELT). Therefore, the purpose of this study was to investigate the breadth and depth of the learning materials prepared in two series of books widely-taught throughout the country through collecting objective evidences and this study concluded by determining comparative analysis of the two series, interchange series and the high school textbooks.

Going through some widely-used analyses and checklists (Byrad, 2001; Candling \& Breen, 1979; Daoud \& CelceMurcia, 1979; Sheldon, 1988; Tucker, 1975; Ur, 1996; Williams, 1983) reveals that the analyses and checklists did not deal with learning objectives directly and did not present intelligence categorizations. They limited content of books to linguistic, psychological, content, discourse, and statistical analyses. The psychological analysis focused on the certain theories of learning supporting the principles of materials preparation. In fact, due to the theories of learning, individual differences did not receive much attention. Ansari and Babaii (2001) categorized universal of features of textbooks as following:

\section{Approach: Dissemination of a vision about the nature of language, learning and their application}

2. Content presentation:

a. Stating purpose and objectives 
b. Selection and its rationale

c. Teacher satisfaction

d. Student satisfaction

3. Physical make-up

\section{Administration concerns}

This categorization seems universal but it does not cater for individual differences and does not include a system of activity, exercise and task preparation to provide learners with different learning objectives and various intelligences. Riazi and Mosallanejad (2010) grouped the textbooks analyses prepared in Iran into three parts:

1. The first group focused on contributing to more successful textbook evaluation studies (Ansari \& Babaii, 2003).

2. The second group evaluated textbooks to determine their strengths and weaknesses (Azizifar et al., 2010; Jahangard, 2007; \& Zohrabi, 2011).

3. The last group worked on discourse features and exploring discourse elements in the textbooks (Darali, 2007; Tavakoli, 1995). They also added the forth group with miscellaneous topics, however, these groups took into account neither learning objectives nor multiple intelligences. Jahangard (2007) listed 13 criteria taken from four textbooks: explicitness of objectives, vocabulary presentation, introducing target community procedures, periodic reviews, textbook layout, easiness of reading, visual material, task, clear instruction, graded materials, authentic language, grammar exercises, and fluency. These criteria did not include any element of learning objectives and multiple intelligences, although levels of understanding could be extracted in graded materials and content types. Additionally, these studies did not present any evidences or clues to tap learning objectives and multiple intelligences.

There are also further studies dealing with examining integrating multiple intelligences into activities, tasks, materials, since they were obliged to facilitate conditions of teaching and learning. Palmberg (2002) conducted a study in Thailand and determined the proportional distribution of exercises created to each of the multiple intelligences. He concluded that $97 \%$ of 30 exercises were categorized as verbal/linguistic, $98 \%$ interpersonal, $25 \%$ intrapersonal, $8 \%$ logical/mathematical, $5 \%$ bodily-kinesthetic, $5 \%$ spatial/visual, $3 \%$ naturalist, $2 \%$ musical, and $6 \%$ natural intelligences. He added that "textbook intelligences profile shows writers' tendency and preference and teachers must be able to assess how well the intelligence profile of the selected course book considers with the majority of intelligence profile found for that learner group" (p. 31). Snider (2001) conducted a study on ten first-year collage German textbooks in order to determine the types of activities that were presented and how the activities engaged multiple intelligences in learners. He identified 41 types of activities but only 11 engaged intelligences other than verbal-linguistic intelligence. He concluded that the texts typically use a limited range of activity types in presenting material to students. Farjami (2002) studied multiple intelligences on 5 groups of textbooks in Iran to determine the frequency and percentage of activities akin to each group of textbooks. The focus of the study was on the activities and exercises in the textbooks. He wrote "the EFL text books and teaching practices in Iran are heavily biased toward verbal and logical intelligences meaning that they are quite dependent on the left hemisphere of the brain and the great potentiality for learning of the right hemisphere of the brain is neglected" (p. 17). Therefore, he tried to bridge the gap between the activities, tasks, exercises and materials oriented forward left brain and activities needed right brain involvement in order to enrich the processes, procedures and strategies of language learning. Shirvani (2010) in a study compared the activities in four books taught in Iran to determine the frequencies of multiple intelligences tapped and finally concluded that Iranian high school textbooks significantly relied on activities which incorporate verbal-linguistic intelligences and most textbooks fully attended to musical, bodily-kinesthetic, and logical, mathematical and naturalist intelligences. However, the frequency of logical-mathematical intelligence is not as least as Shirvani (2010) reported. Also, due to lack of any other rater approval, the figures in the above-mentioned studies are not completely reliable.

Noble $(2002,2004)$ in her studies integrated Bloom's taxonomy with multiple intelligences and presented tools to plan and implement units of work through teaching activities and materials over 18 months in two primary schools. She concluded that there was greater confidence in teacher's ability to broaden their curriculum and cater for student difference strengths across multiple intelligences. She also added that a combination of the typologies of multiple intelligences and Bloom's taxonomy helps teachers gain an integrated model of the different ways that students learn different intellectual domains and work with various thinking capabilities. Although this plan was implemented in primary schools, the major concept lent itself to evaluate some textbooks widely used throughout the country.

As the review of studies show, there is a paucity in determining features of books within these two taxonomies. The studies were conducted either within a general perspective or with a particular view toward the materials. The cognitive aspect of the textbook analysis from these two perspectives renders better ways to teacher to teach in accordance with student's abilities and preferences. The main purpose of this study was to evaluate the textbooks prepared and taught in high schools and in EFL language institutes in Iran to determine the prevalence of materials based on these two taxonomies. The analysis was performed at two levels: one at six levels of learning objectives of Bloom's taxonomy and the other at eight levels of Gardner's multiple intelligences. This study also tried to evaluate texts, tasks, and exercises in the two book series in terms of the two perspectives. The main questions focused upon in this study are as follows:

1. Which levels of the grid are more prevalent in the four books of high school and four books of the interchange series? 
2. How could materials oriented to learning objectives and multiple intelligences in the two book series be compared?

\section{Method}

The researchers used the coding scheme presented by Bloom $(1956,2002)$ and the list of multiple intelligences introduced by Gardner $(1993,1999)$ to code the two series and determine the frequency of evidences of Bloom's taxonomy and Gardner's multiple intelligences. As the literature indicated, one rater and one researcher analysis may create biased or unreliable analysis; therefore, three experienced university professors who had the experience of teaching the two series were asked to choose what materials were included in the grid. The rest that was not unanimously agreed on was excluded from the study by the researchers. Thus the number of materials decreased to some extent. The frequencies of the materials from the two series were calculated and descriptively shown. To determine any significant pattern in the occurrence of different levels in the grid for the two series, chi-square tests were run.

As already mentioned, two series of materials were used to evaluate based on Bloom's taxonomy and Gardner's multiple intelligences. The high school textbooks were published in four volumes by the Ministry of Education in Iran and the interchange series written by Jack C. Richards (2005) were published in four volumes by Cambridge University Press (CUP).

\subsection{Coding Procedures}

This study was conducted based on the coding scheme to evaluate the content of the two books from Bloom's taxonomy and Gardner's multiple intelligences. First, Bloom's and Gardner's definitions of each category were carefully studied and discussed to extract the key concepts and words of each category. The coding scheme for Bloom's taxonomy showed six parts of learning objectives, from knowledge as the simplest to the most complex, evaluation. The coding organization of Bloom's taxonomy included knowledge, comprehension, application, analysis, synthesis, and evaluation. Also, the coding organization for Gardner's taxonomy comprised linguistic intelligence, logical intelligence, visual-spatial intelligence, bodily-kinesthetic intelligence, musical intelligence, interpersonal intelligence, intrapersonal intelligence, and natural intelligence. Then, to mark elements of the content of the two book series focusing on the two taxonomies, three raters determined each related element to include in the gird. These skillful raters were asked to evaluate the books individually. A few items were also excluded from the gird because of disagreement. The intramarker reliability of the girds was 92 and inter-marker reliability was calculated 85 .

\section{Results}

Table 1 presents the frequencies of learning objectives in high school textbooks (1-4). As the table indicates, comprehension $(\% 30)$ and application $(\% 28)$ were the most frequent numbers of learning objectives and evaluation was reported as the least frequent one.

Table 1. Frequency Grid of Learning Objectives in High School Textbooks

\begin{tabular}{lcc}
\hline & Percentage & Frequency \\
\hline Knowledge & $\% 16.5$ & 95 \\
Comprehension & $\% 30$ & 172 \\
Application & $\% 28$ & 161 \\
Analysis & $\% 11.7$ & 67 \\
Synthesis & $\% 11.9$ & 68 \\
Evaluation & $\% 1.7$ & 10 \\
Total & $\% 100$ & 572 \\
\hline
\end{tabular}

While, in table 2, as presented, comprehension (\%27) and application (\%29.5) were the most frequent numbers of learning objectives and the least frequent number was evaluation $(\% 2.3)$ part. These two series were in much accord. The total number of learning objectives in the interchange series outnumbered that of learning objectives in the high school textbooks. 
Table 2. Frequency Grid of Learning Objectives in Interchange Series

\begin{tabular}{lcc}
\hline & Percentage & Frequency \\
\hline Knowledge & $\% 15.7$ & 113 \\
Comprehension & $\% 27$ & 192 \\
Application & $\% 29.5$ & 212 \\
Analysis & $\% 11.5$ & 83 \\
Synthesis & $\% 14$ & 101 \\
Evaluation & $\% 2.3$ & 17 \\
Total & $\% 100$ & 718 \\
\hline
\end{tabular}

The table 3 shows the frequency of multiple intelligences in the interchange series. As it was presented, the most frequent kind of intelligence was linguistic intelligence (\%47) and the least was natural intelligence (\%1.09).

Table 3. Frequency Grid of Intelligences in the Interchange Series

\begin{tabular}{lll}
\hline & Percentage & Frequency \\
\hline Linguistic & $\% 47$ & 300 \\
Logical & $\% 26$ & 167 \\
Spatial & $\% 7.8$ & 50 \\
Kinesthetic & $\% 2.8$ & 18 \\
Musical & $\% 1.7$ & 11 \\
Interpersonal & $\% 10.5$ & 67 \\
Intrapersonal & $\% 2.8$ & 18 \\
Natural & $\% 1.09$ & 2 \\
Total & $\% 100$ & 638 \\
\hline
\end{tabular}

Table 4 indicates the most frequent intelligence in the high school textbooks was linguistic intelligence (\%53) while natural intelligence $(\% 0.4)$ was the least in the grid.

Table 4. Frequency Grid of Intelligences in the High School Textbooks

\begin{tabular}{lcc} 
& Percentage & Frequency \\
\hline Linguistic & $\% 53.5$ & 255 \\
Logical & $\% 25$ & 123 \\
Spatial & $\% 5.6$ & 27 \\
Kinesthetic & $\% 3.9$ & 19 \\
Musical & $\% 0.8$ & 4 \\
Interpersonal & $\% 8.8$ & 42 \\
Intrapersonal & $\% 0.8$ & 4 \\
Natural & $\% 0.4$ & 2 \\
Total & $\% 100$ & 476 \\
\hline
\end{tabular}


Table 5 depicts the number of learning objectives in the high school textbooks and interchange series. In the high school textbooks, book four had the most frequent number of learning objectives, whereas book three had the least. In the interchange series, the most frequent was interchange three and the least one was interchange two.

Table 5. Frequency Grid of Learning Objectives in the Two Series

\begin{tabular}{lll}
\hline & Percentage & Frequency \\
\hline Book1high school & $\% 27$ & 155 \\
Book 2 & $\% 26$ & 149 \\
Book 3 & $\% 20$ & 115 \\
Book 4 & $\% 27$ & 154 \\
Total & $\% 100$ & 573 \\
Interchange & $\% 25$ & 176 \\
Interchange 1 & $\% 23$ & 168 \\
Interchange 2 & $\% 22$ & 160 \\
Interchange 3 & $\% 30$ & 214 \\
Total & $\% 100$ & 718 \\
\hline
\end{tabular}

Table 6 shows the frequency of multiple intelligences in the two series. In the high school textbooks, the most frequent of multiples intelligences was found in book four and the least in book two, while in interchange series, the most frequent was seen in book three and the least was in book one.

Table 6. Frequency Grid of Intelligences in the Two Series

\begin{tabular}{lll}
\hline & Percentage & Frequency \\
\hline Book1high school & $\% 25$ & 120 \\
Book 2 & $\% 24$ & 116 \\
Book 3 & $\% 25$ & 121 \\
Book 4 & $\% 26$ & 123 \\
Total & $\% 100$ & 480 \\
Interchange & $\% 24$ & 153 \\
Interchange 1 & $\% 25$ & 161 \\
Interchange 2 & $\% 26$ & 163 \\
Interchange 3 & $\% 25$ & 161 \\
Total & $\% 100$ & 638 \\
\hline
\end{tabular}

Table 7 shows the incorporation of the two taxonomies across the high school textbooks. Linguistic intelligence (\%53) enjoyed the most frequency across knowledge, comprehension, application, analysis, synthesis and evaluation categories, and comprehension (\%28) and application (\%28) had the most frequency across eight kinds of intelligences as well. On the other side, natural intelligence (\%0.4) was known as the least frequent intelligence across the objectives of learning, and evaluation (\%2.1) was also identified as the least frequent learning objective across all kinds of intelligences. 
Table 7. Total Frequency Grid of High School Textbooks

\begin{tabular}{|c|c|c|c|c|c|c|c|}
\hline High school & Evaluation & Synthesis & Analysis & Application & Comprehension & Knowledge & Total \\
\hline \multirow[t]{2}{*}{ Linguistic } & 8 & 30 & 31 & 72 & 73 & 41 & 255 \\
\hline & $\% 1.7$ & $\% 6.3$ & $\% 6.5$ & $\% 15.1$ & $\% 15.3$ & $\% 8.6$ & $\% 53.5$ \\
\hline \multirow[t]{2}{*}{ Logical } & 2 & 15 & 16 & 36 & 34 & 21 & 124 \\
\hline & $\% 0.4$ & $\% 3.1$ & $\% 3.4$ & $\% 7.5$ & $\% 7.1$ & $\% 4.4$ & $\% 26$ \\
\hline \multirow[t]{2}{*}{ Spatial } & 0 & 3 & 3 & 8 & 9 & 4 & 27 \\
\hline & 0 & $\% 0.6$ & $\% 0.6$ & $\% 1.7$ & $\% 1.9$ & $\% 0.8$ & $\% 5.7$ \\
\hline \multirow[t]{2}{*}{ Kinesthetic } & 0 & 2 & 3 & 7 & 4 & 3 & 19 \\
\hline & 0 & $\% 0.4$ & $\% 0.6$ & $\% 1.5$ & $\% 0.8$ & $\% 0.6$ & $\% 4$ \\
\hline \multirow[t]{2}{*}{ Musical } & 0 & 0 & 1 & 1 & 1 & 1 & 4 \\
\hline & 0 & 0 & $\% 0.2$ & $\% 0.2$ & $\% 0.2$ & $\% 0.2$ & $\% 0.8$ \\
\hline \multirow[t]{2}{*}{ interpersonal } & 0 & 7 & 5 & 12 & 13 & 5 & 42 \\
\hline & 0 & $\% 1.5$ & $\% 1$ & $\% 2.5$ & $\% 2.7$ & $\% 1$ & $\% 8.8$ \\
\hline \multirow[t]{2}{*}{ intrapersonal } & 0 & 0 & 1 & 1 & 1 & 1 & 4 \\
\hline & 0 & 0 & $\% 0.2$ & $\% 0.2$ & $\% 0.2$ & $\% 0.2$ & $\% 0.8$ \\
\hline \multirow[t]{2}{*}{ Natural } & 0 & 0 & 0 & 1 & 1 & 0 & 2 \\
\hline & 0 & 0 & 0 & $\% 0.2$ & $\% 0.2$ & 0 & $\% 0.4$ \\
\hline \multirow[t]{2}{*}{ Total } & 10 & 57 & 60 & 138 & 136 & 76 & 477 \\
\hline & $\% 2.1$ & $\% 11.9$ & $\% 12.6$ & $\% 28.9$ & $\% 28.5$ & $\% 15.9$ & $\% 100$ \\
\hline
\end{tabular}

Table 8 shows the incorporation of the two profiles in the in the interchange series. Linguistic intelligence with $\% 46$ again showed the most frequency across all kinds of learning objectives and natural intelligence with only $\% 1.1$ had the least across the objectives. Out of learning objectives, application (\%27) and comprehension (\%26) were the most frequent and evaluation $(\% 2.7)$ was the least across the intelligences.

Table 8. Total Frequency Grid of Interchange Series

\begin{tabular}{|c|c|c|c|c|c|c|c|}
\hline High school & Evaluation & Synthesis & Analysis & Application & Comprehension & Knowledge & Total \\
\hline \multirow[t]{2}{*}{ Linguistic } & 8 & 33 & 40 & 87 & 79 & 52 & 300 \\
\hline & $\% 1 / 3$ & $\% 5 / 2$ & $\% 6 / 3$ & $\% 13 / 6$ & $\% 12 / 4$ & $\% 8 / 1$ & $\% 46 / 8$ \\
\hline \multirow[t]{2}{*}{ Logical } & 6 & 23 & 25 & 42 & 42 & 29 & 167 \\
\hline & $\% 0 / 9$ & $\% 3 / 6$ & $\% 3 / 9$ & $\% 6 / 6$ & $\% 6 / 6$ & $\% 4 / 5$ & $\% 26 / 1$ \\
\hline \multirow[t]{2}{*}{ Spatial } & 0 & 5 & 7 & 14 & 16 & 8 & 50 \\
\hline & 0 & $\% 0 / 8$ & $\% 1 / 1$ & $\% 2 / 2$ & $\% 2 / 7$ & $\% 1 / 3$ & $\% 8$ \\
\hline \multirow[t]{2}{*}{ Kinesthetic } & 0 & 1 & 2 & 7 & 5 & 3 & 18 \\
\hline & 0 & $\% 0 / 2$ & $\% 0 / 3$ & $\% 1 / 1$ & $\% 0 / 8$ & $\% 0 / 5$ & $\% 2 / 8$ \\
\hline \multirow[t]{2}{*}{ Musical } & 0 & 1 & 1 & 3 & 3 & 3 & 11 \\
\hline & 0 & $\% 0 / 2$ & $\% 0 / 2$ & $\% 0 / 5$ & $\% 0 / 5$ & $\% 0 / 5$ & $\% 1 / 7$ \\
\hline \multirow[t]{2}{*}{ interpersonal } & 3 & 9 & 12 & 16 & 15 & 13 & 67 \\
\hline & $\% 0 / 5$ & $\% 1 / 4$ & $\% 1 / 9$ & $\% 2 / 5$ & $\% 2 / 3$ & $\% 2$ & $\% 10 / 6$ \\
\hline \multirow[t]{2}{*}{ intrapersonal } & 0 & 1 & 2 & 5 & 6 & 4 & 18 \\
\hline & 0 & $\% 0 / 2$ & $\% 0 / 3$ & $\% 0 / 8$ & $\% 0 / 9$ & $\% 0 / 6$ & $\% 2 / 8$ \\
\hline \multirow[t]{2}{*}{ Natural } & 0 & 1 & 1 & 2 & 2 & 1 & 7 \\
\hline & 0 & $\% 0 / 2$ & $0 / 2$ & $\% 0 / 3$ & $\% 0 / 3$ & $\% 0 / 2$ & $\% 1 / 1$ \\
\hline \multirow[t]{2}{*}{ Total } & 17 & 74 & 90 & 176 & 169 & 113 & 639 \\
\hline & $\% 2 / 7$ & $\% 11 / 6$ & $\% 14 / 1$ & $\% 27 / 5$ & $\% 26 / 4$ & $\% 17 / 7$ & $\% 100$ \\
\hline
\end{tabular}

To determine the comparison between the two grids, a chi-square was run that showed a statistically significant difference between them $\left(x^{2}=52.11, \mathrm{df}=7, \rho=0\right)$.

\section{Discussion}

According to the results of the analysis in the two book series, there was more general agreement for presenting students those exercises, tasks, and texts centered on comprehension and application objectives first and then 
knowledge objective with linguistic intelligence orientation across the two book series. The reason may lie in the fact that the authors of the two book series believe that beginners have to work on low cognitive demand tasks in the first step to meet their cognitive needs (Alderson, 2000). This is justified since linguistic intelligence is "the understanding of phonology, syntax, and semantics of language, and its pragmatic uses to convince others of a course of actions, help one to remember information, explain or communicate knowledge, and reflect upon language itself" (Armstrong, 2003, pp. 13-14). Akbari and Hosseini (2008) also argue that high levels of linguistic, logical and interpersonal intelligences may correspond to communication skills and general cognitive abilities, as these high levels of intelligences were found in the two book series in this study. In addition, high school textbooks were not prepared comprehensively enough to embrace all learning objectives compared to the interchange series because the organization of the textbooks was primarily based on structural system of textbook preparation (Yarmohammadi, 2006), whereas the interchange series showed more communicative orientation with tasks that were of high communication value. The linguistic intelligence outnumbered the other intelligences across the two books because the main objectives of these two book series preparation were, as anticipated, to extend lexical knowledge of learners and increase their communicative language ability (Farjami, 2002). The paucity of natural intelligence across the two series showed that these two series of books did not lend themselves to encourage learners to deal with natural environments or talk about natural and biological topics in English. This is hardly surprising since one's ability to deal with other natural creatures has less to do with language learning and learning objectives (Roohani \& Rabiei, 2013).

Tables 7 and 8 show orientations in the two series of books were toward linguistic, logical, and interpersonal intelligences across comprehension and application learning objectives and this is in line with the findings of Akbari and Hosseini's (2008) study and Roohani and Rabiei's (2013) study. The high levels of the two learning objectives (i.e. comprehension and application) represent that the two book series slightly focus on the understanding and pragmatic aspects of a real communication event. Thus, the learners need to be exposed to a variety of well-organized tasks and materials to develop their cognitive and social skills (Brown, 2000). However, these books did not comprise the materials, including different types of intelligences with various learning objectives. Overall, the results show that interchange series was rated far better than the high school textbooks. In addition to the structural organization of the high school textbooks in Iran, teachers give special attention to language skills highly required for passing university entrance exam, not communicative skills for being a competent language user (Cook, 2008). As Riazi and Mosalanejad (2010) stated, the functional aspect of language use received very little attention in the high school textbooks in Iran because the main focus of these textbooks is to emphasize the structural rather than the functional aspect of language.

\section{Conclusion}

As the paper suggests the two perspectives of Bloom's learning objectives and Gardner's multiple intelligences greatly contribute to broadening and deepening language learning processes; however, the two series did not embrace all the required skills and abilities learners need to communicate, but the interchange series enjoyed a better position.

As the results indicate, the most prevalent type of intelligence was linguistic across the two books in comprehension and application learning objectives, whereas natural, intrapersonal, musical, and spatial intelligences were the least in the two book series. To elevate quality of content of the textbooks, a more comprehensive lesson plan needs to be developed that includes all learning objectives across various intelligences and develop cognitive and social skills at intermediate and advanced levels.

\section{References}

Akbari, R., \& Hosseini, K. (2008). Multiple intelligences and language learning strategies: Investigating possible relations. System, 36(2), 141-155.

Alderson, J. C. (2000). Assessing reading. Cambridge: Cambridge University Press.

Ansari, H., \& Babaii, E. (2000). Universal characteristics of EFL/ESL text book. The Internet TESOL Journal, 2, 1-8.

Armstrong, T. (2003). The multiple intelligences of reading and writing: Making the words come alive. Alexandria, VA: ASCD.

Azizifar, A., Koosha, M., \& Lotfi, A. R. (2010). An analytical evaluation of locally product Iranian high school ELT text book. CCSE, 3, 24-75.

Bloom, B. S., Engelhart, M. D., Furst, E. J., Hill, W. H., \& Krathwohl, D. R. (1956). Taxonomy of educational objectives: The classification of educational goals. Handbook I. Cognitive Domain. New York: David McKay.

Bloom, T. (2002). Blooming with multiple intelligences. Learning Matters, 8, 8-12.

Bloom, T. (2004). Integrating the revised Bloom's taxonomy with multiple intelligences. Teacher Collage Record, 106, 65-73.

Brown, D. (2000). Principles of language learning and teaching. London: Longman.

Byrd, P. (2001). Textbooks: Evaluation for selection and analysis for implementation. In M. Celce-Murcia (Eds.), Teaching English as a second or foreign language (pp. 415-427). US: Heinle \& Heinle, Thomsom Learning Inc.

Candlin, C. N., \& Breen, M. P. (1979). Evaluating, adapting and innovating language teaching materials. In C. Yorio, K. Perkins, and J. Schacter (Eds.), On TESOL 79: The learner in focus (pp. 86-108). Washington, D.C.: Teachers of English to Speakers of Other Languages. 
Cook, V. (2008). L2 language user. UK: Multilingual Matters.

Daoud, A. \& Celce-Murcia, M. (1979). Selecting and evaluating a textbook. In M. Celce-Murcia and L. McIntosh (Eds.), Teaching English as a second or foreign language (pp. 302-307). Cambridge, MA: Newbury House Publishers.

Darali, G. (2007). Pragmatics dimension in spectrum text books (Unpublished Master's Thesis). Shiraz University, Shiraz.

Farjami, H. (2002). The applications of MI theory in designing activities and for teaching English (Unpublished Master's Thesis). University of Semnan, Semnan.

Gardner, H. (1993). Frames of mind: The theory of multiple intelligences. New York: Basic Books.

Gardner, H. (1999). Intelligence reframed: Multiple intelligences for the 21st century. New York: Basic Books.

Jahangard, A. (2007). The evaluation of the EFL materials taught at Iranian public high schools. Karen's Linguistics Issues. Retrieved from http://www3.telus.net/linguisticsissues/bymonth.html

Noble, T. (2000). Integrating Gardner's multiple intelligences theory with a revised Bloom 's taxonomy: A new model for school reform? (Unpublished doctoral dissertation). University of Sydney, Sydney.

Noble, T. (2004). Integrating the revised Bloom's taxonomy with multiple intelligences: A planning tool for curriculum differentiation. Teachers College Record, 106, 193-211.

Palmberg, R. (2002). Catering for multiple intelligences in EFL course books. Humanizing Language Teaching, 4, 2231.

Richards, J. C. (2005). Intero ( $3^{\text {rd }}$ ed.). Cambridge: CUP.

Richards, J. C. (2005). Interchange 1 ( $3^{\text {rd }}$ ed.). Cambridge: CUP.

Richards, J. C. (2005). Interchange 2 ( $3^{\text {rd }}$ ed.). Cambridge: CUP.

Richards, J. C. (2005). Interchange 3 ( $3^{\text {rd }}$ ed.). Cambridge: CUP.

Riazi, M., \& Mosalanejad, N. (2010). Evaluation of learning objectives in Iranian and pre-university text book using Bloom's taxonomy. Journal for English as a Second Language, 13, 110-127.

Roohani, A., \& Rabiei, S. (2013). Exploring language learning strategy use: The role of multiple intelligences, proficiency and gender. The Journal of Teaching Language Skills, 5(3), 41-64.

Sheldon, L. (1988). Evaluating ELT textbooks and materials. ELT Journal, 42 (4), 237-246.

Shirvani, K. (2010, October). An MI-based approach to the evaluation of EFL textbooks. Paper presented at the $8^{\text {th }}$ International TELLSI Conference, Tehran, Iran.

Snider, D. (2001). Multiple intelligences theory and foreign language teaching (Unpublished doctoral dissertation). University of Utah, Utah.

Tavakoli, F. (1995). Functional analysis of the dialogues in Iranian senior high school English textbooks (Unpublished Master's Thesis). Allameh Tabatabai University, Tehran.

Tucker, C. A. (1975). Evaluating beginning textbooks. English Teaching Forum, 13, 355-361.

Ur, P. (1996). A course in language teaching: Practice and theory. Cambridge: Cambridge University Press.

Williams, D. (1983). Developing criteria for text book evaluation. ELT Journal, 37, 251-261.

Yarmohammadi, L. (2006). Communication within critical discourse perspectives. Tehran: Hermes Publication.

Zohrabi, M. (2011). Course book development and evaluation for English for general purpose course. CCSE, 4, 24-75. 